\title{
Evaluation of the Factors that Influence the EU Automobile Industry during the Period of Financial Crisis
}

\author{
Assoc. Prof. Dr. Ligita Gaspareniene \\ Mykolas Romeris University \\ Email: ligita.vasiliauskiene@ktu.lt \\ Assoc. Prof. Dr. Rita Remeikiene \\ Mykolas Romeris University \\ Email: rita.remeikiene@mruni.eu
}

Doi:10.5901/mjss.2014.v5n27p1735

\begin{abstract}
Since EU automobile industry has not completely recovered after the recent financial crisis, it is purposeful to identify what factors could have determined the recession of the EU automobile industry. The article is aimed at the evaluation of the factors that influence the automobile industry in the EU during the period of financial crisis. The methods of the research include correlation analysis and multifaceted regression analysis. The research has enabled to establish the impact of macroeconomic factors on the EU automobile production whereas the factors that influence the EU automobile demand have been researched only partly due to non-stationarity of the statistical data. Although the data was differentiated to make it stationary, the differentiation too significantly changed data values and correlation coefficients to make reliable conclusions. For the comprehensive analysis, the Vector Error Correlation Model (VECM) should be applied.
\end{abstract}

Keywords: automobile industry, financial crisis, demand.

\section{Introduction}

Automobile industry is extremely important for the EU economics since it creates nearly 13 billion workplaces and is considered to be the biggest investor in R\&D. However, due to the impact of the financial crisis, this industry has experienced significant losses.

In the scientific literature, automobile industry has been analyzed considering the following aspects: characteristics and historical development - Haugh, et. al. (2010), Ding, Akoorie (2013), Drauz (2013) and others; automobile sales Dargay (2001), Muhammad, et. al. (2012), Erdem, Nazlioglu (2013) and others; the impact of particular factors on automobile industry - oil price - Kumar, Maheswaran (2013); Busse, et. al. (2009), short-run macroeconomic factors Smusin, Makayeva, 2009 and others. However, there is a lack of the comprehensive research on the macroeconomic factors that influence the EU automobile industry. That is why this article is aimed at evaluation of the factors that influence the EU automobile industry during the period of financial crisis. The objectives of the research are as follows: 1 ) to identify the macroeconomic factors that influence automobile industry; 2) to present the methodology of the research; 3 ) to evaluate the factors that influence the EU automobile industry during the period of financial crisis. The object of the research is EU automobile industry. The methods of the research include correlation analysis and multifaceted regression analysis.

\section{Literature Review: Identification of the Macroeconomic Factors that Influence Automobile Industry}

According to Muhammad, et. al. (2012), the main problem faced by EU automobile industry during 2008 - 2012 was automobile demand decrease which, in turn, caused the decline of automobile production. Although the demand started growing in 2010, it failed to reach the pre-crisis level, and in 2012, the production started decreasing again. The analysis of the scientific literature has enabled to identify the macroeconomic factors that influence automobile production and demand (see Table 1). 
Table 1. Macroeconomic factors influencing automobile production and demand (source: compiled by the authors)

\begin{tabular}{|c|c|c|c|}
\hline \multicolumn{2}{|c|}{ The factors influencing automobile production } & \multicolumn{2}{|c|}{ The factors influencing automobile demand } \\
\hline Factor & Author(s) & Factor & Author(s) \\
\hline GDP & $\begin{array}{l}\text { Madlani, Ulvestad, 2012; Haugh, et. } \\
\text { al., } 2010\end{array}$ & GDP & Muhammad, et. al., 2012; Ding, Akoorie, 2013 \\
\hline $\begin{array}{l}\text { Governmental } \\
\text { policy }\end{array}$ & Madlani, Ulvestad, 2012; Drauz, 2013 & GDP per capita & $\begin{array}{l}\text { Haugh, et. al., 2010; APEC Automotive } \\
\text { Dialogue, } 2002\end{array}$ \\
\hline Exchange rate & Madlani, Ulvestad, 2012; Drauz, 2013 & Fuel prices & Muhammad, et. al., 2012; Busse, et. al., 2009 \\
\hline $\begin{array}{l}\text { Price of raw } \\
\text { material }\end{array}$ & $\begin{array}{l}\text { Madlani, Ulvestad, 2012; Ford Motor } \\
\text { Company, } 2012\end{array}$ & Interest rate & $\begin{array}{l}\text { Muhammad, et. al., 2012; Haugh, et. al., } \\
\text { 2010; Erdem, Nazlioglu, } 2013\end{array}$ \\
\hline Petroleum price & $\begin{array}{l}\text { Ford Motor Company, 2012, Kumar, } \\
\text { Maheswaran, } 2013\end{array}$ & Unemployment rate & Muhammad, et. al., 2012 \\
\hline Interest rate & Ford Motor Company, 2012 & Income level & Dargay, 2001; Smusin, Makayeva, 2009 \\
\hline Public debt & Ford Motor Company, 2012 & Inflation & $\begin{array}{l}\text { Muhammad, et. al., 2012; APEC Automotive } \\
\text { Dialogue, } 2002\end{array}$ \\
\hline \multirow[t]{9}{*}{ Demand } & European Commission, 2008 & Private sector consumption & Haugh, et. al., 2010 \\
\hline & & Petroleum price & $\begin{array}{l}\text { Haugh, et. al., 2010, Abu-Eisheh, Mannering, } \\
2002\end{array}$ \\
\hline & & Financial state of the markets & Haugh, et. al., 2010, Ding, Akoorie, 2013 \\
\hline & & $\begin{array}{l}\text { Customers' (un)certainty } \\
\text { about the future }\end{array}$ & $\begin{array}{l}\text { Haugh, et. al., 2010, APEC Automotive } \\
\text { Dialogue, } 2002\end{array}$ \\
\hline & & Customers' priorities & Erdem, Nazlioglu, 2013 \\
\hline & & International trade & Erdem, Nazlioglu, 2013 \\
\hline & & Manufacturing & $\begin{array}{l}\text { Erdem, Nazlioglu, 2013; Smusin, Makayeva, } \\
2009\end{array}$ \\
\hline & & Exchange rate & $\begin{array}{l}\text { Ludvigson, 1998; APEC Automotive Dialogue, } \\
2002\end{array}$ \\
\hline & & Real estate price & Smusin, Makayeva, 2009 \\
\hline
\end{tabular}

As it can be seen in Table 1, automobile production is influenced by GDP, governmental policies, exchange rate, price of raw material, petroleum price, interest rate, public debt and demand. Among the factors that have the significant impact on automobile demand, the main ones emphasized in the scientific literature are interest rate, petroleum prices and income level.

What is more, the scientific literature contains the research on the links between different factors that have the impact on automobile industry and demand. The summary of the scientific research to analyse the strength of the links between particular macroeconomic factors and automobile demand has been presented in Table 2 .

Table 2. Strength of the links between macroeconomic factors and automobile demand (source: compiled by the authors)

\begin{tabular}{|c|c|c|c|}
\hline Author(s) & Weak link & Medium link & Strong link \\
\hline Haugh, et. al., 2010 & & & Private consumption \\
\hline Muhammad, et. al. (2012) & & & $\begin{array}{l}\text { GDP, inflation, unemployment rate, } \\
\text { interest rate* }\end{array}$ \\
\hline Smusin, Makayeva, 2009 & $\begin{array}{l}\text { Inflation, interest } \\
\text { rates }\end{array}$ & GDP, exchange rate & Manufacturing, real estate prices \\
\hline $\begin{array}{l}\text { Abu-Eisheh, Mannering, } \\
2002\end{array}$ & & & GDP, employment \\
\hline $\begin{array}{l}\text { Kumar, Maheswaran, } \\
2013\end{array}$ & & & Petroleum price \\
\hline Ludvigson, 1998 & & & Exchange rate \\
\hline Busse, et. al., 2009 & & $\begin{array}{l}\text { Petroleum price, income level, } \\
\text { exchange rate }\end{array}$ & \\
\hline Dargay, 2001 & & Income level & \\
\hline
\end{tabular}

Table 2 shows that automobile industry moves along economics. However, the variation of automobile production is 
bigger than that of GDP; new automobile registration is strongly positively linked with GDP and employment while the link between sales and income level as well as the one between sales and exchange rate is medium-strength positive. Negative medium-strength link was established between sales and petroleum prices while automobile demand and interest rate showed a strong negative link. Finally, automobile demand is strongly positively influenced by income level.

Summarizing, it can be stated that GDP has positive impact on automobile industry since rising economics increases consumption and production. Income increase has positive impact on sales while inflation causes automobile demand to decrease. The demand also decreases due to the negative impact of unemployment rate, petroleum prices and interest rates. Increasing foreign currency rates reduce automobile demand while strong domestic currencies raise the demand due to cheaper imports. Private consumption positively affects automobile demand. All these factors can have indirect impact on automobile production since it is dependent on consumption.

\section{The methodology of the research}

The analysis was performed in the following stages: 1) assessment of the collected data; 2) correlation analysis; 3) model preparation and evaluation.

In the first stage, the data was collected and data normality, i.e. normal distribution, was verified. Then data stationarity was verified applying autocorrelation function (ACF). For data significance verification, $Q$ statistics, particularly Ljung-Box (LB) test, was applied. If the coefficients of $Q$ statistics were significant, the variable was differentiated to get stationarity. If ACF stationarity failed, Augmented Dickey-Fuller (ADF) test was applied.

In the second stage, the links between dependent and independent variables were verified applying regression and correlation. Researching the correlation, automobile production and demand volumes were treated as dependent variables (y) while macroeconomic factors were treated as independent variables (x). Linear correlation was calculated using Pearson correlation coefficient. For correlation verification, t (Student's) criterion was applied.

In the third stage, regression model was prepared and verified. Significance of the model was verified applying Fisher criterion. Durbin-Watson statistics was applied verifying autocorrelation of the model. Also, residual errors, their normality and possible heteroscedasticity (i.e. whether the errors do not correlate with independent variables) were verified. The analysis was carried out using "Eviews" software.

\section{Evaluation of the factors that influence the EU automobile industry during the period of financial crisis}

The empirical research has enabled to identify the factors that influence the EU automobile production and demand during the period of financial crisis.

The statistics of automobile production has been presented in annual data; the data of the period of $1997-2012$, i.e. 16 observants, has been considered.Since the values of Jaeque-Bera (JB) criterion (0.93) are higher than 0.05, the data has normal distribution. Since JB criterion for GDP is lower than 0.05 , this criterion will not be further analyzed. Q statistics for automobile production and 1 month EURIBOR are higher than 0.05 , so these variables are stationary, and they will not be differentiated as well as the variable of new automobile registration since their probabilities are also close to 0.05 .

In the second stage of the analysis, the correlation matrix has been formed (see Table 3).

Table 3. EU automobile production dependence on macroeconomic factors (source: compiled by the authors)

\begin{tabular}{|c|c|c|c|c|c|c|c|c|c|}
\hline & $\begin{array}{l}\text { Produc- } \\
\text { tion }\end{array}$ & $\begin{array}{l}\text { New } \\
\text { automobile } \\
\text { registration }\end{array}$ & $\begin{array}{l}\text { GDP } \\
\text { (D) }\end{array}$ & $\begin{array}{l}\text { Petroleum } \\
\text { price (D) }\end{array}$ & $\begin{array}{c}\text { Steal } \\
\text { price } \\
\text { index (D) }\end{array}$ & $\begin{array}{c}\text { Real } \\
\text { exchange } \\
\text { rate (D) }\end{array}$ & $\begin{array}{c}\text { Public } \\
\text { debt (D) }\end{array}$ & $\begin{array}{c}1 \text { month } \\
\text { EURI- } \\
\text { BOR }\end{array}$ & $\begin{array}{l}\text { Loan } \\
\text { interest } \\
\text { rate }\end{array}$ \\
\hline Production & 1 & & & & & & & & \\
\hline New automobile registration & 0.726 & 1 & & & & & & & \\
\hline GDP (D) & 0.653 & 0.465 & 1 & & & & & & \\
\hline Petroleum price (D) & 0.653 & 0.138 & 0.646 & 1 & & & & & \\
\hline Steal price index (D) & 0.573 & 0.205 & 0.315 & 0.776 & 1 & & & & \\
\hline Real exchange rate (D) & 0.093 & 0.204 & -0.150 & -0.209 & 0.152 & 1 & & & \\
\hline Public debt (D) & -0.522 & -0.462 & -0.877 & -0.398 & -0.195 & 0.012 & 1 & & \\
\hline 1 month EURIBOR & 0.417 & 0.625 & 0.477 & 0.110 & 0.219 & 0.204 & -0.685 & 1 & \\
\hline Loan interest rate & 0.450 & 0.604 & 0.454 & 0.173 & 0.258 & 0.083 & -0.641 & 0.976 & 1 \\
\hline
\end{tabular}


With the reliability level a equal to 0.05 , and the variables including 15 observants (one observant was lost due to differentiation), the calculated critical value of $t$ criterion was 2.160. Comparing this value with $t$ values for independent variables, it was established that 3 variables have lower $t$ values than the critical one. Thus, their correlation is insignificant and the variables of real exchange rate (0.338), 1 month EURIBOR interest rate (1.656) and loan interest rate (1.817) will not be used for further research. Values $t$ for the other variables are higher than the critical value, and probabilities lower than 5 per cent, so their correlations with the dependent variable are significant. Thus, the rest part of the variables have medium or strong link with the dependent variable. New automobile registration strongly correlates with automobile production.

Independent variables GDP (0.653) and petroleum price (0.653) have a positive medium-strength link with automobile production. Growing economics determines automobile production growth. However, the positive link between petroleum price and automobile production is illogical since petroleum is one of main raw materials in this industry. What is more, higher petroleum prices cause fuel prices to rise, which, in turn, leads to automobile demand and production decline. That is why the variable of petroleum price will not be used for further research as well as the variable of steal price index which has strong correlation (0.573) with automobile production. Steal is also an important raw material in automobile industry, so higher steal prices cause more expensive automobile production, which, in turn, discourages customers from buying automobiles.

Public debt is the only of the variables that is negatively linked with automobile production. The link between public debt and automobile production is also medium-strength (-0.522). Increasing public debt causes the decline in automobile production. High public debt can impede economic growth and so negatively affect automobile production.

As it can be seen in the correlation matrix presented above, the variables of GDP and public debt show strong correlation (the value is higher than 0.7 ). That is why both of the variables cannot be used in one model. The variable of public debt has been eliminated. The completed model has been presented in Table 4.

Table 4. Automobile production multifaceted regression model (compiled by the authors)

\begin{tabular}{|c|c|c|c|c|}
\hline \multicolumn{5}{|c|}{$\begin{array}{l}\text { Dependent Variable: AUTO_MANUFACTURING } \\
\text { Method: Least Squares } \\
\text { Date: } 05 / 15 / 14 \text { Time: 02:21 } \\
\text { Sample (adjusted): } 19982012 \\
\text { Included observations: } 15 \text { after adjustments } \\
\text { AUTO_MANUFACTURING=C(1)+C(2)*AUTO_REGIS+C(3)*DGDP }\end{array}$} \\
\hline & Coefficient & Std. Error & t-Statistic & Prob. \\
\hline & 8608746. & 2953474. & 2.914786 & 0.0130 \\
\hline & 0.518542 & 0.184771 & 2.806410 & 0.0159 \\
\hline & 1.969281 & 0.936800 & 2.102135 & 0.0573 \\
\hline R-squared & 0.654076 & \multicolumn{2}{|c|}{ Mean dependent var } & 17413945 \\
\hline Adjusted R-squared & 0.596423 & \multicolumn{2}{|c|}{ S.D. dependent var } & 1111881. \\
\hline S.E. of regression & 706352.8 & \multicolumn{2}{|c|}{ Akaike info criterion } & 29.95047 \\
\hline Sum squared resid & $5.99 \mathrm{E}+12$ & \multicolumn{2}{|c|}{ Schwarz criterion } & 30.09208 \\
\hline Log likelihood & -221.6286 & \multicolumn{2}{|c|}{ Hannan-Quinn criter. } & 29.94897 \\
\hline F-statistic & 11.34487 & \multicolumn{2}{|c|}{ Durbin-Watson stat } & 0.808483 \\
\hline
\end{tabular}

Table 4 reveals that the model is significant since the probability of $F$ statistics is lower than 0.05 . The coefficients of independent variables are significant as well. Although the probability of t statistics for GDP is slightly higher than 0.05 , it is very close to this number, so it is treated as significant.

Model's determination coefficient R2shows that the variables of new automobile registration and GDP explain 65.4 per cent changes of the dependent variable - automobile production. The determination coefficient, adjusted considering the variables, show that the variables of new automobile registration and GDP explain automobile production by 59.6 per cent. The coefficient of the variables in the model reveals that registration of one new automobile would increase automobile production by 0.52 automobile. The influence of GDP is difficult to estimate since this variable was differentiated.

Autocorrelation in the model has been verified applying Durbin-Watson statistic. Considering the number of independent variables and observants in the model, the values of $\mathrm{dL}$ and dUwere selected. The model includes 2 independent variables and 15 observants; $d L=0.95$, and $d U=1.54$. In the model, $d=0.81$. Since this value is lower than 
both critical values, the model contains positive autocorrelation of errors. That is why model's determination coefficient cannot be treated as reliable.

Summarizing the results, it can be stated that automobile production in the EU is strongly positively influenced by automobile demand (new automobile registration) and GDP. Also, the factor of public debt has medium-strength correlation with automobile production. Medium-strength correlation of petroleum price and steal price index with automobile production cannot not be logically substantiated. The model of multifaceted regression that includes the variables of GDP and new automobile registration explains automobile production by 59.6 per cent. However, the model contains autocorrelation, so the results are not completely reliable.

For the research of automobile demand factors, the data of the quarters during the period of 2003 - 2012, i.e. 40 observants, was analysed.

The probability of JB criterion for the dependent variable - new automobile registration - is higher than 0.05 , so the data of this variable has normal distribution. The probability of JB criterion for the other two variables - GDP and GDP per capita -is lower than 0.05 , i.e. the data of these variables does not have any normal distribution; the variables have negative values and cannot be computed as a logarithm. That is why the variables of GDP and GDP per capita will not be used for further research.

Verifying stationarity of the variables, it has been estimated that probabilities of $\mathrm{Q}$ statistics for all variables are lower than 0.05 , so all the variables are non-stationary.

First grade differentiation has enabled to reach stationarity for six variables: gross wages, GDP per capita, vehicle price index, petroleum price, real efficient currency exchange and household consumption expenditure.

What is more, other six variables (GDP, loan interest rate, 1 month EURIBOR, unemployment rate, consumer confidence index and manufacturing index) had to be differentiated by the second grade in order to reach their stationarity. However, five variables did not reach their stationarity by $\mathrm{Q}$ statistics even after the second grade differentiation. Then another method, i.e. Augmented Dickey-Fuller (ADF) test, was applied. The variable of disposable income growth, differentiated by first grade ADF, reached its stationarity while the other four variables (disposable income, long-term goods consumption expenditure, consumer price index and new automobile registration) were differentiated by second grade.

In the second stage of the research, the correlation matrix has been formed (see Table 5).

Table 5. EU automobile demand dependence on macroeconomic factors (compiled by the authors)

\begin{tabular}{lclc}
\hline & New automobile registration & New automobile registration \\
\hline Gross wages & -0.265 & Disposable income & 0.246 \\
\hline GDP & -0.040 & Disposable income growth & 0.236 \\
\hline GDP per capita & -0.175 & Consumer confidence index & -0.083 \\
\hline 1 month EURIBOR & -0.249 & Loan interest rate & -0.069 \\
\hline Consumer price index & 0.309 & Manufacturing index & 0.005 \\
\hline Vehicle price index & 0.038 & Real efficient currency exchange & 0.208 \\
\hline Petroleum price & -0.170 & Household consumption expenditure & -0.255 \\
\hline Unemployment rate & 0.086 & Long-term goods consumption expenditure & 0.321 \\
\hline
\end{tabular}

With the reliability level a equal to 0.05 , and the variable including 38 observants (2 observants were lost due to differentiation), the calculated critical value of $t$ criterion was 2.0281 . Only one variable, i.e. long-term goods consumption expenditure, significantly correlates with automobile demand (new automobile registration). However, the correlation is weak (0.321). It shows that the increasing expenditure for long-term goods partly determines new automobile registration. In addition, probability of t statistics for consumer price index (0.0594) is close to 0.05 , thus, this variable can be treated as significant. However, correlation of this variable with new automobile registration is illogical since increasing prices should not determine higher demand for automobiles. Thus, there remains only one significant variable which fails the formation of a multifaceted regression model, and the model of pair regression shows very low determination coefficient.

Summarizing, the analysis of the macroeconomic factors that have the impact on the EU automobile demand has partly failed due to non-stationarity of the statistical data. Data differentiation significantly changes its values and correlation coefficients. Thus, in the future, the analysis of this kind should be carried out applying the Vector Error Correlation Model (VECM). 


\section{Conclusions}

Researching the influence of macroeconomic factors, it has been established that new automobile registration and GDP have significant positive impact on the EU automobile production. Public debt has a positive medium-strength correlation with it. The factors of GDP and new automobile registration can explain 60 per cent of the changes of automobile production in the EU.

The factors that influence the EU automobile demand have been researched only partly due to non-stationarity of the statistical data. Although the data was differentiated to make it stationary, the differentiation too significantly changed data values and correlation coefficients to make reliable conclusions. For the comprehensive analysis, the Vector Error Correlation Model (VECM) should be applied.

\section{References}

Abu-Eisheh, S. A. \& Mannering, F. L. (2002). Forecasting Automobile Demand for Economies in Transition. A Dynamic SimultaneousEquation System Approach, Transportation Planning and Technology, 25 (4), 311-331.

APEC Automotive Dialogue (2002). Effective Automotive Policies and Barriers to Growth, Joint Industry. Report for APEC Automotive Dialogue, 1-7.

Busse, M. R., Knittel C.R. \& Zettelmeyer F. (2009). Pain at the Pump: The Effect of Gasoline Prices on New and Used Automobile Markets, NBER Working Papers, No. 15590, 1-56.

Dargay, J. M. (2001). The effect of income on car ownership: evidence of asymmetry. Transportation Research, 2001, Part A, Nr. 35, p 807-821.

Ding, Q. \& Akoorie, M. E. M. (2013).The characteristics and historical development path of the globalizing Chinese automobile industry. Journal of Technology Management in China, 8 (2), 83-104.

Drauz, R. (2013). In search of a Chinese internationalization theory: a study of 12 automobile manufacturers. Chinese Management studies, 7 (2), 281-309.

Erdem, C. \& Nazlioglu, S. (2013). Determinants of New Vehicle Registrations in EU countries: a Panel Cointegration Analysis. Transportation Planning and Technology, 36(3), 287-298.

European Commission (2008). European Competitiveness Report 2008, Office for Official Publications of the European Communities, ISBN 978-92-79-09773-7.

Ford Motor Company (2012). Annual Report, 2012, [online], [accessed 21-07-2014]. Available at <http://corporate.ford.com/doc/sr12annual-report-2012.pdf>

Haugh, D., Mourougane, A. \& Chatal, O. (2010). The Automobile Industry in and Beyond the Crisis. OECD Economics Department Working Papers, №. 745, 1-36.

Kumar, D. \& Maheswaran, S. (2013). Correlation transmission between crude oil and Indian markets. South Asian Journal of Global Business Research, 2(2), 211-229.

Ludvigson, S. (1998). The Channel of Monetary Transmission to Demand: Evidence from the Market for Automobile Credit. Journal of Money, Credit, and Banking, 30(3), 365-383.

Madlani, J. \& Ulvestad, J.C. A. (2012). Fundamental Valuation of the BMW Group, Master Thesis, Copenhagen Business School.

Muhammad, F., Hussin, M. Y. M. \& Razak, A. A. (2012). Automobile Sales and Macroeconomic Variables: A Pooled Mean Group Analysis for Asian Countries. Journal of Business and Management, 2(1), 15-21.

Smusin, V. \& Makayeva, N. (2009). Short-run macroeconomic factors affecting car sales. Modern Management Research Conference(MMRC): Insights into the sustainable growth of business, Vilnius, ISSN 2029-3461. 